\title{
MYCOBACTERIUM AVIUM SUBSP. PARATUBERCULOSIS AND THE EXPRESSION OF SELECTED VIRULENCE AND PATHOGENESIS GENES IN RESPONSE TO $6^{\circ} \mathrm{C}, 6^{\circ} \mathrm{C}$ AND PH 2.0
}

\section{Radka Pribylova ${ }^{1}$, Petr Kralik ${ }^{1}$, Neysan Donnelly ${ }^{1,2}$, Jan Matiasovic ${ }^{1}$, Ivo Pavlik $^{1^{*}}$}

${ }^{1}$ Veterinary Research Institute, Hudcova 70, 62100 Brno, Czech Republic; ${ }^{2}$ University of Aberdeen, King's College, Aberdeen AB24 3FX, United Kingdom.

Submitted: December 14, 2009; Approved: November 04, 2010.

\begin{abstract}
The aim of this work was to study the expression of selected Mycobacterium avium subsp. paratuberculosis $(M A P)$ genes connected with MAP virulence, adhesion and stress response. The temperature of $6^{\circ} \mathrm{C}$ and $65^{\circ} \mathrm{C}$ were chosen with regard to the food industry, storage conditions (refrigerator) and low-temperature pasteurization. A pH of 2.0, using lactic acid, was selected to mimic the natural environment of the stomach. Expression of selected genes was studied using real time reverse transcription PCR on three different MAP isolates. MAP isolates were chosen according to the number of their preceding cultivations. While isolates 8672 and 8819 were previously cultivated only once, MAP isolate 12146 went through four passages. Different expression profiles were observed in each of the three MAP isolates. However, particular similar patterns were observed. SigE, $\operatorname{sig} F$ and $a h p C$ were up-regulated, while sigL was down-regulated under temperature stress. Mmp gene was found to be down-regulated under acidic conditions. Low passage isolates (8672 and 8819) showed certain level of acid resistance.
\end{abstract}

Key words: MAP; Johne's disease; stress; treatment; real time PCR

\section{INTRODUCTION}

Mycobacterium avium subsp. paratuberculosis $(M A P)$ is a slender, non-spore-forming, aerobic bacterium. Its main features are the requirement for Mycobactin in growth media, and slow growth, which complicates its cultivation and diagnosis. MAP is the causal agent of a chronic inflammation of the intestine called paratuberculosis or Johne's disease (in Anglo-Saxon countries), which affects mainly domestic ruminants, but also other animal species. The disease is characterised by a loss of physical condition and weight, emaciation, decreased milk production and diarrhoea $(3,13$, 18, 24,). Additionally, MAP is considered to be one of the possible causes of Crohn's disease (CD) in humans $(7,8,26$, 27, 37). The most frequent sources of $M A P$ for humans are from contaminated drinking water, water aerosol, milk (1416) or even meat (1).

Transcriptional control represents the major mechanism in gene expression regulation in prokaryotes and so the measurement of RNA transcripts provides an accurate picture

*Corresponding Author. Mailing address: Veterinary Research Institute, Hudcova 70, 62100 Brno, Czech Republic.; Tel.: +420 53333 1601. Fax: +420 5 4121 1229.; E-mail: pavlik@vri.cz 
of the cell's response to a given stress. The detection and quantification of gene expression levels can be investigated by many methods such as Northern blotting (2), S1 nuclease protection (6), sequencing of cDNA libraries (29) or serial analysis of gene expression - SAGE (43). Nowadays, real time reverse transcription qPCR (real time RT-qPCR) and microarray technology represent the most used techniques for expression profiling studies $(45,47)$.

The purpose of the present study was to investigate the MAP gene expression after inducing stress factors such as temperature and acid environment in vitro. The temperatures of $6^{\circ} \mathrm{C}$ and $65^{\circ} \mathrm{C}$ were chosen with regard to the storage conditions (refrigerator) and low-temperature pasteurization used in the food industry, respectively. A stress factor of $\mathrm{pH}$ 2.0 was selected with regard to the acid environment in the stomach. Appropriate candidate genes were selected for their involvement in the virulence, adhesion and stress response in $M A P$ or other mycobacterial infections.

The most plentiful group was represented by sigma factors - transcriptional regulators, which are involved in all gene expression $(23,36,44)$. Nineteen sigma factors are encoded by MAP genome (22). Mammalian cell entry (mce) genes represented the second largest group of tested genes; they were identified in many mycobacteria, and have been described to be important for pathogenesis $(20-22,31)$. UmaA1, papA2, $k d p C$ and impA were investigated due to their role in various pathways contributing to colonisation of host tissues (38). The macrophage-induced gene ( $m i g$ ) and the major membrane protein gene $(\mathrm{mmp})$ were selected because of their apparent involvement in virulence $(4,5,11,33,34)$. Kat $G$ gene encodes the catalase-peroxidase enzyme contributing to mycobacterial survival in macrophages by protecting the cells against hydrogen peroxide $(12,19)$. In its absence, antioxidant protection is provided by an increased expression of $a h p C$, which is itself reduced by $a h p D$ (30). Finally gapdh and $1 g 2$ were selected as MAP housekeeping genes (12).

\section{MATERIALS AND METHODS}

\section{Bacterial isolates}

Three MAP cattle field isolates (12146, 8672 and 8819) from the Czech Republic were used. Isolates Nos. 8672 and 8819 were obtained from clinically manifested cows, while isolate No. 12146 originated from a healthy cow. Nevertheless, all isolates tested positive after cultivation on Middlebrook 7H9 with Middlebrook AODC enrichment, BD PANTA antibiotic mixture (all Becton Dickinson, Franklin Lakes, NJ, USA) and Mycobactin J (1 mg/l; Allied Monitor, Fayette, MO, USA). While isolates 8672 and 8819 went through preceding cultivation once, the third isolate, 12146, had been subcultivated four times (under the same conditions as previous two isolates). The MAP suspensions were inoculated into Middlebrook $7 \mathrm{H} 9$ broth supplemented with Mycobactin J ( $1 \mathrm{mg} / \mathrm{l}$; Allied Monitor, USA) and OADC (Becton Dickinson, USA). Cells were incubated with shaking at $37^{\circ} \mathrm{C}$ for 5 to 10 weeks to $\log$ phase. All isolates were confirmed for the presence of IS900 using real time qPCR (40; data not showed).

\section{MAP treatments in vitro}

Six $\mathrm{ml}$ of each MAP isolate in the log phase were transferred into glass tubes and subjected to $6^{\circ} \mathrm{C}, 65^{\circ} \mathrm{C}$ and lactic acid (LA) treatment. The tubes were exposed to $6^{\circ} \mathrm{C}$ and $65^{\circ} \mathrm{C}$ for $30 \mathrm{~min}$. To ensure the acquirement of $65^{\circ} \mathrm{C}$ in the whole volume of MAP culture, tubes were exposed to "preheating" step (measured in the sealed glass tubes with $6 \mathrm{ml}$ of $M A P$ and containing a thermometer). The total time of $65^{\circ} \mathrm{C}$ temperature treatment, including the "pre-heating" step was determined as $31 \mathrm{~min}$ and $50 \mathrm{~s}$. In the case of $\mathrm{pH}$ treatment, the appropriate concentration of LA (5\%) was added into a tube containing $6 \mathrm{ml}$ of $M A P$ culture to obtain a $\mathrm{pH}$ of 2.0. The mixture was agitated for 2 minutes. A sample without any treatment was prepared to serve as a control. All experiments were carried out in two physical duplicates. 


\section{RNA isolation}

Immediately after treatments, guanidine thiocyanate (4M, Sigma, St. Louis, MO, USA) was added to treated and untreated MAP cultures. The solution was allowed to stand at room temperature for $30 \mathrm{~min}$ prior to centrifugation $(3,026 \times \mathrm{g}$ for $10 \mathrm{~min}$ at $4^{\circ} \mathrm{C}$ ). The pellet was resuspended in $600 \mu \mathrm{l}$ of TriReagent (Sigma, USA) and homogenised with $0.1 \mathrm{~mm}$ Zirconia beads (BioSpec Inc., Bartlesville, OK, USA) using the MagnaLyser instrument (Roche Molecular Diagnostic, Penzberg, Germany) at $6,500 \mathrm{rpm}$ for $15 \mathrm{~s}$. The sample was homogenised a further three times with cooling on ice for 2 min between each step. Homogenised samples were transferred into a new tube, $100 \mu \mathrm{l}$ of chloroform was added, gently mixed and centrifuged $(10,000 \times \mathrm{g}$ for $10 \mathrm{~min}$ at RT). The upper phase was transferred into a new tube and $350 \mu$ of RLT buffer was added (RNeasy kit, Qiagen, Hilden, Germany). Subsequently, the RNeasy kit (Qiagen, Germany) was used for RNA isolation with these modifications: $250 \mu \mathrm{l}$ of $98 \%$ ethanol was added to the mixture with RLT buffer and all centrifugation steps were carried out at $8,000 \times \mathrm{g}$ for $20 \mathrm{~s}$. RNA was eluted using $50 \mu \mathrm{l}$ of RNase, DNase free water. The elution was repeated with the same filtrate again (RNA isolation according to Dr. Tim Bull, St. George's Hospital Medical School, London, UK; personal communication).

\section{DNase treatment and reverse transcription (RT)}

$10 \mathrm{U}$ of DNase I was applied to RNA samples according to the manufacturer's instructions (Roche Molecular Diagnostic, Germany). The reaction contained $40 \mu \mathrm{l}$ of isolated RNA in a total volume of $50 \mu \mathrm{l}$. Incubation was carried out at $37^{\circ} \mathrm{C}$ for $30 \mathrm{~min}$, followed by enzyme inactivation at $75^{\circ} \mathrm{C}$ for $5 \mathrm{~min}$. After the first incubation, an additional $10 \mathrm{U}$ of enzyme was added and the incubation and inactivation step was repeated. The RT mix contained $20 \mathrm{U}$ of Avian Myeloblastosis Virus-reverse transcriptase $(\mathrm{AMV}-\mathrm{RT})$ and $1 \times$ reaction buffer (Finnzyme, Espoo, Finland), $40 \mathrm{nmol}$ of all dNTPs (Finnzyme, Finland), $40 \mathrm{U}$ of Ribonuclease Inhibitor (Takara Bio Inc,
Otsu, Japan), 1 pmol of each reverse primer (see Table 1), and $20 \mu \mathrm{l}$ of DNase treated RNA. The mix was brought to a final volume of $40 \mu \mathrm{l}$ using RNase free water. Reverse transcription was performed at $42^{\circ} \mathrm{C}$ for 60 min. After RT, cDNA was purified using the MinElute qPCR Purification Kit (Qiagen, Germany) with final elution into $100 \mu \mathrm{l}$ of TE buffer (Amresco, Solon, OH, USA).

\section{Real time qPCR}

Real time qPCR mixes were made up to a final volume of $10 \mu \mathrm{l}$ and contained $1 \times$ of DyNAmo Probe qPCR Master Mix (Finnzyme, Finland), 0.1 U of Uracil DNA Glycosylase (Roche Molecular Diagnostic, Germany), 5 pmol of each forward and reverse primer, 0.5 pmol of each probe labelled with FAM and $1 \mu \mathrm{l}$ of appropriate cDNA. Primers and probes were designed using Primer3 software (35) on a MAP K10 strain genomic sequence (GenBank AE016958) and synthesised by VBC Genomics, Austria (Table 1). Gapdh primers were described previously in Granger et al. (12). qPCR was performed using the LightCycler 480 Instrument (Roche Molecular Diagnostic, Germany) using 96-well qPCR plates under the following conditions: initial denaturation at $95^{\circ} \mathrm{C}$ for $15 \mathrm{~min}$ followed by 45 cycles of $95^{\circ} \mathrm{C}$ for $5 \mathrm{~s}$ and $60^{\circ} \mathrm{C}$ for $30 \mathrm{~s}$ (fluorescence data collection). Subsequent analysis was carried out using the "Second derivative maximum" option of the LightCycler 480 software (version 1.2.0.0625). All qPCR were done in triplicates.

\section{Calculation of relative expression level}

To determine the most suitable housekeeping genes for data normalization, the stability of genes was tested using geNorm software (42). Relative expression levels of selected genes were calculated according to the modified $\Delta \Delta \mathrm{Ct}$ method, which also takes into account real time qPCR efficiencies (32). Twice up- or down-regulated gene expression difference was considered to be significant $(46,48)$. The efficiency of real time qPCR for each set of primers and respective probes 
(essential for the calculation of relative expression levels) was determined from serial dilutions of MAP isolate No. 12146 cDNA (1, 10, 100 and 1000 times diluted) in fish sperm DNA (Serva, Heidelberg, Germany). Real time PCR followed the above mentioned protocol.

\section{Determination of $M A P$ viability after the treatment}

$M A P$ viability was assessed by the propidium monoazide PMA-PCR (28). Briefly, from each culture (with treated or untreated control cells), two aliquots of $250 \mu 1$ were delivered to individual tubes. One of them was subjected to PMA (Biotium, Inc, Hayward, CA, USA) treatment. Then, both tubes with PMA treated and untreated cells suspensions were centrifuged at $5,000 \times \mathrm{g}$ for $5 \mathrm{~min}$ and the supernatant was removed. $250 \mu \mathrm{l}$ of the fish sperm DNA (Serva, Germany) dissolved in TE buffer (50 ng/ $\mu \mathrm{l}$; Amresco, USA) was added to the pellet. The $M A P$ cells were lysed at $100^{\circ} \mathrm{C}$ for $20 \mathrm{~min}$, the suspension was then centrifuged and the supernatant served as a template for F57 real time qPCR (40). Each sample was analysed in physical duplicate. For the determination of the $M A P$ viability, the quotient of the absolute amount of $M A P$ cells treated with PMA and without PMA was determined for respective MAP strain and treatment (control). By using this approach, we were able to determine the percentage of the $M A P$ live cells, and to assess the effect of the treatment.

Table 1. Primers and probes used for the expression analysis in Mycobacterium avium subsp. paratuberculosis

\begin{tabular}{|c|c|c|c|}
\hline Target & Name & Sequence & PCR product \\
\hline & $1 \mathrm{~g} 2-\mathrm{F}$ & aaacgatttgaacaaggtgctc & \\
\hline \multirow[t]{3}{*}{$\lg 2$} & $1 \mathrm{~g} 2-\mathrm{R}$ & cgaatagggcgctgaatg & 119 bp \\
\hline & $1 \mathrm{~g} 2-\mathrm{TM}$ & FAM-atggaaggccacgaggcggatt-BHQ & \\
\hline & GAPDH-F $^{\mathrm{a}}$ & atcgggcgcaacttctacc & \\
\hline \multirow[t]{3}{*}{ gapdh } & GAPDH-R ${ }^{\mathrm{a}}$ & gtcgaatttcagcaggtgagc & $123 b p$ \\
\hline & GAPDH-TM & FAM-acgacatcaccgacaacagcacc-BHQ & \\
\hline & $35 \mathrm{kDa}-\mathrm{F}$ & cggagcagacgatccaga & \\
\hline \multirow[t]{3}{*}{$m m p$} & $35 \mathrm{kDa}-\mathrm{R}$ & ggcgtcttccacaccttg & 82 bp \\
\hline & $35 \mathrm{kDa}-\mathrm{TM}$ & FAM-acgacctcgacgcgctgatc-BHQ & \\
\hline & mod-F & gcatcaaccaggacagcac & \\
\hline \multirow[t]{3}{*}{ fap-p } & $\bmod -\mathrm{R}$ & gtcgctgaatttcacctcgta & $83 b p$ \\
\hline & mod-TM & FAM-ctcaacggcgccaacggaag-BHQ & \\
\hline & umaA1-F & ttgacctacacccagaagcag & \\
\hline \multirow[t]{3}{*}{ umaAl } & umaA1-R & gaaccgtaaatcgctcatcg & $66 b p$ \\
\hline & umaA1-TM & FAM-cagcacgagcgcggcgtt-BHQ & \\
\hline & papA2-F & ggcgttcccacagaatcc & \\
\hline \multirow[t]{3}{*}{ papA2 } & papA2-R & cagacacatcgecetgac & $73 b p$ \\
\hline & papA2-TM & FAM-cgattcggtcgagcgctacatc-BHQ & \\
\hline & kdpC-F & caccgttcgtgagcctct & \\
\hline \multirow[t]{3}{*}{$k d p C$} & $\mathrm{kdpC}-\mathrm{R}$ & atctggccgagcgaatagt & $76 b p$ \\
\hline & kdpC-TM & FAM-cgcgtcgaatgcgccaaga-BHQ & \\
\hline & impA-F & ctgacctggttgccgttc & \\
\hline \multirow[t]{2}{*}{$\operatorname{impA}$} & impA-R & gcgggatttcgttcttgc & $76 \mathrm{bp}$ \\
\hline & impA-TM & FAM-ctcgaccagcgctacaccgc-BHQ & \\
\hline
\end{tabular}




\begin{tabular}{|c|c|c|c|}
\hline & mce2-F & atccgcgetatgtcaacc & \\
\hline \multirow[t]{2}{*}{ mce2 } & mce2-R & cgtacttgttgccgaacagc & $78 \mathrm{bp}$ \\
\hline & mce2-TM & FAM-tgattccggcgaacgtggtg-BHQ & \\
\hline & mce3-F & caacacatcctgtcgattctc & \\
\hline \multirow[t]{3}{*}{ mce3 } & mce3-R & tggttgtcggtgatggtg & $62 \mathrm{bp}$ \\
\hline & mce3-TM & FAM-tcggcgagcaccaccagc-BHQ & \\
\hline & mce4-F & gacgctgggcatcaacag & \\
\hline \multirow[t]{3}{*}{ mce4 } & mce4-R & gccgaagatggtgttaccg & 82 bp \\
\hline & mce4-TM & FAM-tccaacgccaccgtgcacatc-BHQ & \\
\hline & mig-F & ggccatatcgagctgctg & \\
\hline \multirow[t]{3}{*}{ mig } & mig-R & cgtctcgacctcctcgac & $81 \mathrm{bp}$ \\
\hline & mig-TM & FAM-actccgtgtgcatcaattccgg-BHQ & \\
\hline & $\operatorname{sig} \mathrm{A}-\mathrm{F}$ & gatggcgttcctcgatttg & \\
\hline \multirow[t]{3}{*}{$\operatorname{sig} A$} & $\operatorname{sig} \mathrm{A}-\mathrm{R}$ & agccettggtgtagtcgaac & $80 \mathrm{bp}$ \\
\hline & sigA-TM & FAM-cctgatccgtgcggtcgagaa-BHQ & \\
\hline & sigD-F & ccgtcgatgacaattccag & \\
\hline \multirow[t]{3}{*}{$\operatorname{sig} D$} & sigD-R & ggagtgcgttgtggtctcc & 79 bp \\
\hline & sigD-TM & FAM-aacgtctcgatgctgtggtcgc-BHQ & \\
\hline & sigE-F & gtgtaccggctggcetac & \\
\hline \multirow[t]{3}{*}{$\operatorname{sig} E$} & sigE-R & ccggatgaaggtctcctg & $75 \mathrm{bp}$ \\
\hline & sigE-TM & FAM-aatcagcacgacgccgaggac-BHQ & \\
\hline & sigF1-F & gacgcagagccagatagcc & \\
\hline \multirow[t]{3}{*}{$\operatorname{sig} F 1$} & sigF1-R & agggtgtttgecaggatg & $72 \mathrm{bp}$ \\
\hline & sigF1-TM & FAM-cgtctcgcagatgcaggtctcg-BHQ & \\
\hline & sigF2-F & gcagctcctacaacaccttg & \\
\hline \multirow[t]{3}{*}{$\operatorname{sig} F 2$} & sigF2-R & cgcacttcetcetcttcg & $61 \mathrm{bp}$ \\
\hline & sigF2-TM & FAM-tccatcgacagcggcggc-BHQ & \\
\hline & sigH-F & gaccaacacctacatcaacagc & \\
\hline \multirow[t]{3}{*}{$\operatorname{sig} H$} & sigH-R & gatttcctcggtcggatactc & $70 \mathrm{bp}$ \\
\hline & sigH-TM & FAM-taccgcaagaagcagcgccag-BHQ & \\
\hline & sigL-F & cgtgatcgaacggtcctact & \\
\hline \multirow[t]{3}{*}{$\operatorname{sig} L$} & sigL-R & cgatgccgaggtctgtagc & $65 \mathrm{bp}$ \\
\hline & sigL-TM & FAM-cggttggaccaccgcgcagata-BHQ & \\
\hline & katG-F & caaccagggcaagttcgtc & \\
\hline \multirow[t]{3}{*}{$k a t G$} & katG-R & aagcggtcgttgttcatcac & $66 \mathrm{bp}$ \\
\hline & katG-TM & FAM-aggacttcgtcgcggcctg-BHQ & \\
\hline & ahpC-F & ctgaagaacctgccgttcc & \\
\hline \multirow[t]{3}{*}{$a h p C$} & ahpC-R & cgtcggcgttgagaacac & 79 bp \\
\hline & ahpC-TM & FAM-ctctcggacatcaagcgcgaact-BHQ & \\
\hline & ahpD-F & gaacatcatcggcaatcc & \\
\hline \multirow[t]{2}{*}{$a h p D$} & ahpD-R & gaaacggcgaagcaccac & $63 \mathrm{bp}$ \\
\hline & ahpD-TM & FAM-cgtggagaaggcgaacttcgagct-BHQ & \\
\hline
\end{tabular}

${ }^{\mathrm{a}}$ Primers were taken from Granger et al. 2004 


\section{RESULTS}

The testing of stability using geNorm software showed different stabilities of $1 g 2$ and gapdh genes in different MAP isolates under various stress conditions (Fig. 1). As no other genes (from the set of 22) were found be suitable for use as a housekeeping gene for all three isolates, the geometric mean (GM) of all Cts (cycle thresholds) within the respective treatment (control) for each strain was calculated and used as a "normalization reference". Normalization using the GM has been described for larger set of data and represents a way of obtaining accurate expression profiles of tested genes (42). The relative expression levels for each $M A P$ isolate are shown in Fig. 2. A two-fold change in expression was used as mentioned above.

$M A P$ isolate 8672 showed seven up-regulated genes under temperature treatments $6^{\circ} \mathrm{C}$ and $65^{\circ} \mathrm{C}$, which was the highest number of up-regulated genes from all tested isolates (Fig. 2). Isolate 8819 responded with 5 up-regulations, while only two up-regulations were observed in isolate 12146. Expression profiles were different in different isolates, nevertheless, a similar pattern was found. SigE was up-regulated in both 8672 and 8819 treated at $65^{\circ} \mathrm{C}$. The same situation was noted with the gene $\operatorname{sig} F 2$ under $6^{\circ} \mathrm{C}$, although the expression in isolate 8819 was slightly under the limit of two. Similarly, $a h p C$ was up-regulated in 8672 , and was slightly below two in the isolate 12146 under the stress of $65^{\circ} \mathrm{C}$ (Fig. 2). SigL was the only common gene found to be down-regulated in two isolates (8819 and 8672).

With regards to the results of acidic treatments, the reverse was determined when comparing temperature stresses (Fig. 2). MAP isolate 12146 showed the highest level of response to this stress factor. Three genes (gaphd, papA2 and sigD,) were upregulated in isolate 12146 when compared to one $\operatorname{ahpC}$, and no up-regulated gene in isolates 8672 and 8819, respectively. Each 8819 and 12146 showed down-regulation in two cases ( $\mathrm{mmp}$, mig and impA genes), whereas one down-regulated gene was noted in isolate 8672 (mce2). In both 12146 and 8819 isolates, the $m m p$ gene was down-regulated. The correlation between stress factors and cell viability is shown in Table 2.
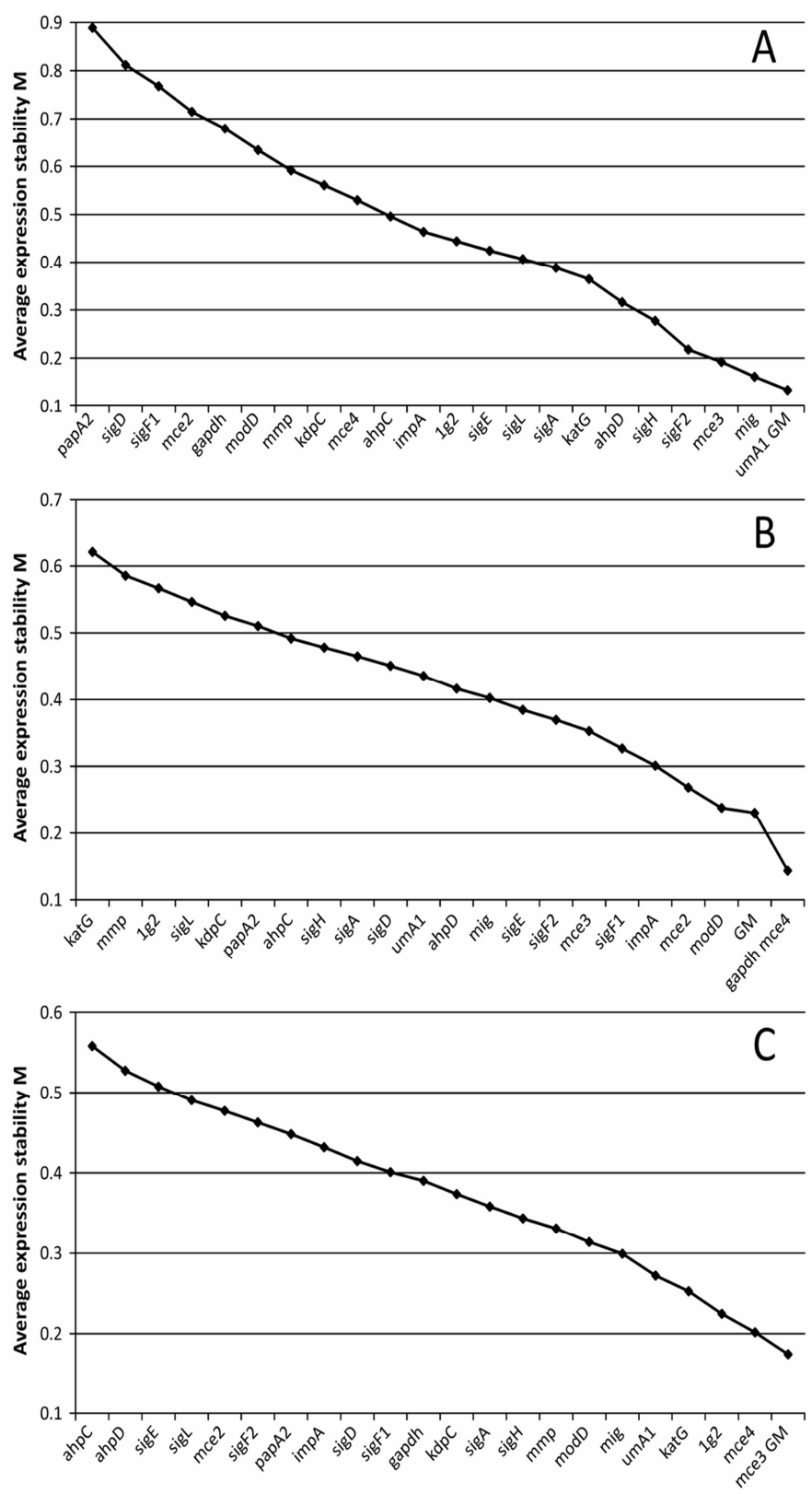

Figure 1. The average expression stability (M) of selected genes for the Mycobacterium avium subsp. paratuberculosis strains 12146 (A), 8819 (B) and 8672 (C) measured by GeNorm software. The lower M value the more stable gene. 

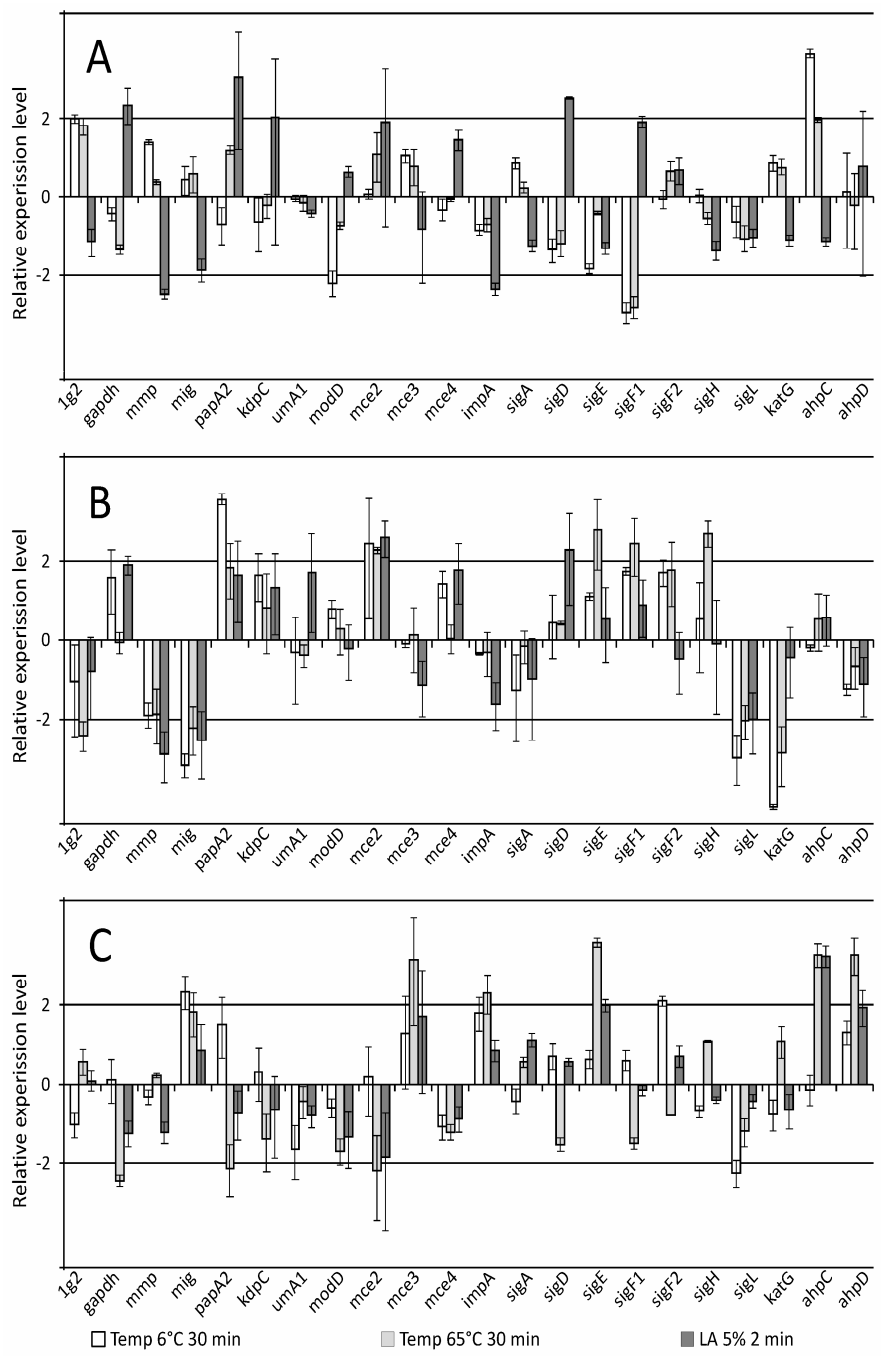

Figure 2. The relative gene expression levels (in log scale) of Mycobacterium avium subsp. paratuberculosis strains 12146 (A), 8819 (B) and 8672 (C). Numbers on y axis represent multiples of up- (positive values) and down- (negative values) regulation.

Table 2. Percentage of viable Mycobacterium avium subsp. paratuberculosis cells after treatments as determined by $F 57$ real time qPCR

\begin{tabular}{cccc}
\hline & $\boldsymbol{M A P ~ 1 2 1 4 6}$ & $\boldsymbol{M A P ~ 8 6 7 2}$ & $\boldsymbol{M A P ~ 8 8 1 9}$ \\
\hline $6^{\circ} \mathrm{C}$ & 100.5 & 104.3 & 102.8 \\
$65^{\circ} \mathrm{C}$ & 21.17 & 12.86 & 14.24 \\
$\mathrm{pH} 2$ & 25.33 & 32.25 & 36.95 \\
\hline
\end{tabular}

All calculations were done as the quotient of MAP cells treated with PMA and without PMA for the respective MAP strain.

\section{DISCUSSION}

The expression of virulence determinants in bacteria can be controlled by environmental signals, especially by temperature and low iron concentration, but osmolarity, $\mathrm{pH}$, oxygen or $\mathrm{CO}_{2}$ can play an important role as well (25). The goal of this study was to determine the influence of certain stress factors used in the food industry (storage conditions, low-temperature pasteurization and the presence of lactic acid) on the expression profiles of representatively selected genes involved in virulence, pathogenesis and stress response of MAP. A thorough examination of internet databases was carried out and suitable candidate genes were selected. The complete package contained 22 tested genes; two of them assumed to be housekeeping genes.

Two genes, $\lg 2$ and gapdh, were selected to serve as housekeeping genes according to the literature (12). As they were previously described to be constitutively expressed in $M A P$, it was not confirmed in our study. None of the other genes were proven to be uniform for all three MAP strains therefore the strategy using a GM had to be adopted for normalization (42). This strategy is based on the principle that the mean expression level of a sufficiently large pool of genes is similar in all samples, regardless of the experimental conditions. Changes in the expression of a small portion of genes due to experimental conditions cannot change the overall mean of the expression ratio (49). For every control gene, the pairwise variation with all other control genes is determined as the standard deviation, and the internal control gene stability measure (M) is defined (42). Using the geNorm software, the GM was determined as the most stable (in 12146 and 8672 isolate) and second most stable (in 8819 isolate) "gene" (Fig. 1). We are aware that this study is the first to combine the use of GM and real time RT-qPCR for the determination of the reference gene. Although it is rather employed in the analysis of larger gene sets, we think that it could be utilised in real time RT-qPCR, especially when no suitable housekeeping genes are available. 
Expression of the $m m p$ gene was suppressed in both isolates 12146 and 8819 as a reaction to a low pH. In 8672 isolate $m m p$ expression did not differ from the control sample. The $m m p$ gene encodes a $35 \mathrm{kDa}$ major membrane protein (4, 5). Its transcription increases under high osmolarity and low oxygen tension, while no transcription occurs when exposed to acidic $\mathrm{pH}$ or standard aerobic growth conditions (5). Generally, 8819 isolate did not response at all under $\mathrm{pH}$ stress, while 12146 showed the highest number of up-regulated genes.

In all three MAP isolates, different genes were downregulated under temperature stress. The transcription of $\operatorname{sig} L$ was suppressed under $6^{\circ} \mathrm{C}$ in both 8672 and 8819 . SigL belongs to a family of transcriptional regulators. Hahn et al. (17) suggested sigL regulates the synthesis of cell envelope lipids and is responsible for the modification of secreted proteins in M. tuberculosis. They also found, sigL does not play a role in responding to oxidative stress. In MAP, two (8672 and 8819; Fig. 2) of three isolates showed decreased expression of $\operatorname{sig} L$ after cold shock. Also, it seems, sigL is not affected in by heat shock $\left(45^{\circ} \mathrm{C}\right)$, acidic $\mathrm{pH}$, and hyperosmolarity in $M$. tuberculosis (9). According to this study, higher temperature did not lead to changes in sigL expression in any of $M A P$ isolates (Fig. 2).

$45^{\circ} \mathrm{C}$ heat shock led to lower expression of $\operatorname{sig} F$ in a $M$. smegmatis study using the $\beta$-galactosidase enzyme as a reporter gene, whereas cold shock $\left(15^{\circ} \mathrm{C}\right)$ led to higher expression of $\operatorname{sig} F$ when compared to the control (39). In M. tuberculosis, Manganelli et al. (23) observed no variation in the transcriptional level of $\operatorname{sig} F$ after cold shock, which is in contrast with the study of DeMaio et al. (10) who found upregulation of $\operatorname{sig} F$ after cold shock in $M$. bovis BCG. In this study with MAP isolates, it seems, cold temperature leads to up-regulation of $\operatorname{sig} F$ (MAP isolates 8672 and 8819; Fig. 2) rather than to its down-regulation.

Under high temperature stress $\left(65^{\circ} \mathrm{C}\right)$, the increased transcription of genes $\operatorname{sig} F$ and $\operatorname{sig} E$ was observed in isolates 8672 and 8819 . The up-regulation of $\operatorname{sig} E$ has been observed after heat shock previously $(23,36)$. Wu et al. (46) describe the role of sigE in MAP virulence and pathogenesis, as this gene was co-regulated with a large number of other highly regulated genes. At $65^{\circ} \mathrm{C}$, the transcription of $a h p C$ and $a h p D$ was also increased in isolate 8672. In isolate 12146, expression of ahpC was very slightly below the level of a two-fold change expression (1.95; Fig. 2). AhpC and $a h p D$ genes encode detoxifying enzymes used for the protection against reactive nitric and oxidative metabolites. Olsen et al. (30), nevertheless, described a strong expression of the ahp genes in vitro without the bacteria being exposed to any oxidative stress.

The expression profiles of all three tested strains were different. The high passage isolate No. 12146 responded mostly to the acid treatment, when compared to the other two low passage MAP isolates. On the contrary, a relatively low change in 12146 gene expression during temperature stress was observed (Fig. 2). Sung and Collins (41) observed that a higher proportion of low passage MAP clinical isolates were sensitive to heat when compared to high passage strains. Thus, the temperature resistance of 12146 isolate (Tab. 2) rather reflects higher number of its previous passages than its real feature. On the contrary, isolate No. 8672 and 8819 mostly responded to temperature stress, while only a limited response to lactic acid stress was noticed (Fig. 2). As both 8672 and 8819 isolates went through preceding cultivation only once, a weaker reaction to acidic stress (Tab. 2, Fig. 2) could indicate a real level of their acid tolerance. As both these isolates originated from animals with manifested paratuberculosis, this feature could correspond with their pathogenesis and higher level of virulence.

This paper investigates the effect of temperature and $\mathrm{pH}$ stress on the expression of selected MAP genes connected to virulence and pathogenesis. Using three $M A P$ isolates, various levels of gene expression for different genes were obtained, but certain similar patterns in expression were observed. Generally, the transcription of $\operatorname{sig} F$ was up-regulated under $6^{\circ} \mathrm{C}$, while the transcription of $\operatorname{sigL}$ was down-regulated. Under higher 
temperature stress $\left(65^{\circ} \mathrm{C}\right)$, the expression of $\operatorname{sig} E$ and $a h p C$ were found to be over-expressed comparing to control samples. Under acidic conditions, the expression of gene encoding the major membrane protein ( $\mathrm{mmp}$ ) was found to be decreased. Dissimilarities in gene expression in various $M A P$ isolates most probably corresponded with the number of previous cultivations. Nevertheless, certain level of acid resistance was shown in low passage 8672 and 8819 isolates.

\section{ACKNOWLEDGEMENTS}

The authors would like to especially thank Dr. Tim Bull (Department of Cardiovascular Sciences-Surgery, St. George's Hospital Medical School, London, UK) for providing the method for RNA isolation. Also we thank to Vladimir Grof (Veterinary Research Institute, Brno, Czech Republic) for helping with pictures. This work was supported by the Ministry of Agriculture, Czech Republic grant No. MZE0002716202 and QH81065, the Ministry of Education, Youth and Sports of the Czech Republic (project AdmireVet No. CZ.1.05/2.1.00/01.0006-ED 0006/01/01) and by the EC project FOOD-CT-2005-007081 (PathogenCombat).

\section{REFERENCES}

1. Abubakar, I.; Myhill, D.J.; Hart, A.R.; Lake, I.R.; Harvey, I.; Rhodes, J.M.; Robinson, R.; Lobo, A.J.; Probert, C.S.J.; Hunter, P.R. (2007). A case-control study of drinking water and dairy products in Crohn's disease - further investigation of the possible role of Mycobacterium avium paratuberculosis. Am. J. Epidemiol. 165, 776-783.

2. Alwine, J.C.; Kemp, D.J.; Stark, G.R. (1977). Method for detection of specific RNAs in agarose gels by transfer to diazobenzyloxymethylpaper and hybridization with DNA probes. P. Natl. Acad. Sci. USA 74, 5350-5354.

3. Ayele, W.Y.; Machackova, M.; Pavlik, I. (2001). The transmission and impact of paratuberculosis infection in domestic and wild ruminants. Veterinarni Medicina 46, 205-224.

4. Banasure, K.D.; Basagoudanavar, S.H.; Chaudhury, P.; Tiwari, V.; Parihar, N.S.; Goswami, P.P. (2001). Identification and characterization of a gene encoding a 35-kDa protein from Mycobacterium avium subspecies paratuberculosis. FEMS Microbiol. Lett. 196, 195-199.

5. Bannantine, J.P.; Huntley, J.F.J.; Miltner, E.; Stabel, J.R.; Bermudez, L.E. (2003). The Mycobacterium avium subsp paratuberculosis $35 \mathrm{kDa}$ protein plays a role in invasion of bovine epithelial cells. Microbiol.SGM 149, 2061-2069.

6. Berk, A.J.; Sharp, P.A. (1977). Sizing and mapping of early adenovirus mRNAs by gel electrophoresis of S1 endonuclease-digested hybrids. Cell 12, 721-732.

7. Bull, T.J.; McMinn, E.J.; Sidi-Boumedine, K.; Skull, A.; Durkin, D.; Neild, P.; Rhodes, G.; Pickup, R.; Hermon-Taylor, J. (2003). Detection and verification of Mycobacterium avium subsp. paratuberculosis in fresh ileocolonic mucosal biopsy specimens from individuals with and without Crohn's disease. J. Clin. Microbiol. 41, 2915-2923.

8. Cheng, J.; Bull, T.J.; Dalton, P.; Cen, S.; Finlayson, C.; Hermon-Taylor, J. (2005). Mycobacterium avium subspecies paratuberculosis in the inflamed gut tissues of patients with Crohn's disease in China and its potential relationship to the consumption of cow's milk: A preliminary study. World J. Microb. Biot. 21, 1175-1179.

9. Dainese, E.; Rodrigue, S.; Delogu, G.; Provvedi, R.; Laflamme, L.; Brzezinski, R.; Fadda, G.; Smith, I.; Gaudreau, L.; Palu, G.; Manganelli, R. (2006). Posttranslational regulation of Mycobacterium tuberculosis extracytoplasmic-function sigma factor $\operatorname{sigma}(\mathrm{L})$ and roles in virulence and in global regulation of gene expression. Infect. Immun. 74, 24572461.

10. DeMaio, J.; Zhang, Y.; Ko, C.; Young, D.B.; Bishai, W.R. (1996). A stationary-phase stress-response sigma factor from Mycobacterium tuberculosis. P. Natl. Acad. Sci. USA 93, 2790-2794.

11. Glawischnig, W.; Steineck, T.; Spergser, J. (2006). Infections caused by Mycobacterium avium subspecies avium, hominissuis, and paratuberculosis in free-ranging red deer (Cervus elaphus hippelaphus) in Austria, 2001-2004. J. Wildlife Dis. 42, 724-731.

12. Granger, K.; Moore, R.J.; Davies, J.K.; Vaughan, J.A.; Stiles, P.L.; Stewart, D.J.; Tizard, M.L.V. (2004). Recovery of Mycobacterium avium subspecies paratuberculosis from the natural host for the extraction and analysis in vivo-derived RNA. J. Microbiol. Meth. 57, 241-249.

13. Grant, I.R. (2005). Zoonotic potential of Mycobacterium avium ssp paratuberculosis: the current position. J. Appl. Microbiol. 98, 12821293.

14. Grant, I.R.; Ball, H.J.; Rowe, M.T. (1999). Effect of higher pasteurization temperatures, and longer holding times at 72 degrees $\mathrm{C}$, on the inactivation of Mycobacterium paratuberculosis in milk. Lett. Appl. Microbiol. 28, 461-465.

15. Grant, I.R.; Ball, H.J.; Rowe, M.T. (2002). Incidence of Mycobacterium paratuberculosis in bulk raw and commercially pasteurized cows' milk from approved dairy processing establishments in the United Kingdom. Appl. Environ. Microb. 68, 2428-2435. 
16. Grant, I.R.; O'Riordan, L.M.; Ball, H.J.; Rowe, M.T. (2001). Incidence of Mycobacterium paratuberculosis in raw sheep and goats' milk in England, Wales and Northern Ireland. Vet. Microbiol. 79, 123-131.

17. Hahn, M.Y.; Raman, S.; Anaya, M.; Husson, R.N. (2005). The Mycobacterium tuberculosis extracytoplasmic-function sigma factor SigL regulates polyketide synthases and secreted or membrane proteins and is required for virulence. J. Bacteriol. 187, 7062-7071.

18. Hasonova, L.; Pavlik, I. (2006). Economic impact of paratuberculosis in dairy cattle herds: a review. Veterinarni Medicina 51, 193-211.

19. Heym, B.; Zhang, Y.; Poulet, S.; Young, D.; Cole, S.T. (1993). Characterization of the katG gene encoding a catalase-peroxidase required for the isoniazid susceptibility of Mycobacterium tuberculosis. J. Bacteriol. 175, 4255-4259.

20. Kumar, A.; Bose, M.; Brahmachari, V. (2003). Analysis of expression profile of mammalian cell entry (mce) operons of Mycobacterium tuberculosis. Infect. Immun. 71, 6083-6087.

21. Kumar, A.; Chandolia, A.; Chaudhry, U.; Brahmachari, V.; Bose, M. (2005). Comparison of mammalian cell entry operons of mycobacteria: in silico analysis and expression profiling. FEMS Immunol. Med. Mic. 43, 185-195.

22. Li, L.L.; Bannantine, J.P.; Zhang, Q.; Amonsin, A.; May, B.J.; Alt, D.; Banerji, N.; Kanjilal, S.; Kapur, V. (2005). The complete genome sequence of Mycobacterium avium subspecies paratuberculosis. P. Natl. Acad. Sci. USA 102, 12344-12349.

23. Manganelli, R.; Dubnau, E.; Tyagi, S.; Kramer, F.R.; Smith, I. (1999). Differential expression of 10 sigma factor genes in Mycobacterium tuberculosis. Mol. Microbiol. 31, 715-724.

24. Manning, E.J.; Collins, M.T. (2001). Mycobacterium avium subsp. paratuberculosis: pathogen, pathogenesis and diagnosis. Rev. Sci. Tech. OIE 20, 133-150.

25. Mekalanos, J.J. (1992). Environmental signals controlling expression of virulence determinants in bacteria. J. Bacteriol. 174, 1-7.

26. Nakase, H.; Nishio, A.; Tamaki, H.; Matsuura, M.; Asada, M.; Chiba, T.; Okazaki, K. (2006). Specific antibodies against recombinant protein of insertion element 900 of Mycobacterium avium subspecies paratuberculosis in Japanese patients with Crohn's disease. Inflamm. Bowel Dis. 12, 62-69.

27. Naser, S.A.; Ghobrial, G.; Romero, C.; Valentine, J.F. (2004). Culture of Mycobacterium avium subspecies paratuberculosis from the blood of patients with Crohn's disease. Lancet 364, 1039-1044.

28. Nocker, A.; Cheung, C.Y.; Camper, A.K. (2006). Comparison of propidium monoazide with ethidium monoazide for differentiation of live vs. dead bacteria by selective removal of DNA from dead cells. $J$. Microbiol. Meth. 67, 310-320.

29. Okubo, K.; Hori, N.; Matoba, R.; Niiyama, T.; Fukushima, A.; Kojima, Y.; Matsubara, K. (1992). Large scale cDNA sequencing for analysis of quantitative and qualitative aspects of gene expression. Nat. Genet. 2, 173-179.

30. Olsen, I.; Reitan, L.J.; Holstad, G.; Wiker, H.G. (2000). Alkyl hydroperoxide reductases $\mathrm{C}$ and $\mathrm{D}$ are major antigens constitutively expressed by Mycobacterium avium subsp paratuberculosis. Infect. Immun. 68, 801-808.

31. Paustian, M.L.; Kapur, V.; Bannantine, J.P. (2005). Comparative genomic hybridizations reveal genetic regions within the Mycobacterium avium complex that are divergent from Mycobacterium avium subsp paratuberculosis isolates. J. Bacteriol. 187, 2406-2415.

32. Pfaffl, M.W. (2001). A new mathematical model for relative quantification in real-time RT-PCR. Nucleic Acids Res. 29, e45.

33. Plum, G.; Brenden, M.; Clark-Curtiss, J.E.; Pulverer, G. (1997). Cloning, sequencing, and expression of the mig gene of Mycobacterium avium, which codes for a secreted macrophage-induced protein. Infect. Immun. $65,4548-4557$.

34. Plum, G.; Clarkcurtiss, J.E. (1994). Induction of Mycobacterium avium gene expression following phagocytosis by human macrophages. Infect. Immun. 62, 476-483.

35. Rozen, S.; Skaletsky, H. (2000). Primer3 on the WWW for general users and for biologist programmers. In: Misener, S.; Krawetz, S.A. (eds). Methods in Molecular Biology, vol. 132: Bioinformatics Methods and Protocols. Humana Press Inc., Totowa NJ, USA, p. 365-386.

36. Sechi, L.A.; Felis, G.E.; Ahmed, N.; Paccagnini, D.; Usai, D.; Ortu, S.; Molicotti, P.; Zanetti, S. (2007). Genome and transcriptome scale portrait of sigma factors in Mycobacterium avium subsp. paratuberculosis. Infect. Genet. Evol. 7, 424-432.

37. Sechi, L.A.; Scanu, A.M.; Molicotti, P.; Cannas, S.; Mura, M.; Dettori, G.; Fadda, G.; Zanetti, S. (2005). Detection and isolation of Mycobacterium avium subspecies paratuberculosis from intestinal mucosal biopsies of patients with and without Crohn's disease in Sardinia. Am. J. Gastroenterol. 100, 1529-1536.

38. Shin, S.J.; Wu, C.W.; Steinberg, H.; Talaat, A.M. (2006). Identification of novel virulence determinants in Mycobacterium paratuberculosis by screening a library of insertional mutants. Infect. Immun. 74, 3825-3833.

39. Singh AK, Singh BN (2008). Conservation of sigma F in mycobacteria and its expression in Mycobacterium smegmatis. Curr. Microbiol. 56: 574-580.

40. Slana, I.; Kralik, P.; Kralova, A.; Pavlik, I. (2008). On-farm spread of Mycobacterium avium subsp paratuberculosis in raw milk studied by IS900 and F57 competitive real time quantitative PCR and culture examination. Int. J. Food Microbiol. 128, 250-257.

41. Sung, N.; Collins, M.T. (1998). Thermal tolerance of Mycobacterium paratuberculosis. Appl. Environ. Microb. 64, 999-1005.

42. Vandesompele, J.; De Preterm K.; Pattyn, F.; Van Roy, N.; De Paepe, A.; Speleman, F. (2002). Accurate normalization of real-time 
quantitative RT-PCR data by geometric averaging of multiple internal control genes. Genome Biol. 3, 0034.1-0034.11.

43. Velculescu, V.E.; Zhang, L.; Vogelstein, B.; Kinzler, K.W. (1995). Serial analysis of gene expression. Science 270, 484-487.

44. Waagmeester, A.; Thompson, J.; Reyrat, J.M. (2005). Identifying sigma factors in Mycobacterium smegmatis by comparative genomic analysis. Trends Microbiol. 13, 505-509.

45. Weiss, D.J.; Evanson, O.A.; Deng, M.; Abrahamsen, M.S. (2004). Gene expression and antimicrobial activity of bovine macrophages in response to Mycobacterium avium subsp paratuberculosis. Vet. Pathol. 41, 326337.

46. Wu, C.W.; Schmoller, S.K.; Shin, S.J.; Talaat, A.M. (2007). Defining the stressome of Mycobacterium avium subsp. paratuberculosis in vitro and in naturally infected cows. J. Bacteriol. 189, 7877-7886.

47. Xiang, Z.Y.; Yang, Y.N.; Ma, X.J.; Ding, W. (2003). Microarray expression profiling: Analysis and applications. Curr. Opin. Drug Disc. 6, 384-395.

48. Yang, I.V.; Chen, E.; Hasseman, J.P.; Liang, W.; Frank, B.C.; Wang, S.; Sharov, V.; Saeed, A.I.; White, J.; Li, J.; Lee, N.H.; Yeatman, T.J.; Quackenbush, J. (2002). Within the fold: assessing differential expression measures and reproducibility in microarray assays. Genome Biol. 3, 0062.

49. Zhang, A. (2006). Data normalization - Global normalization approaches. In Zhang, A., (ed). Advanced analysis of gene expression microarray data. World Scientific Publishing Co., Hackensack, NJ, USA, p. $46-47$. 